\title{
A REGULAÇÃO REGISTRAL DAS SOCIEDADES SIMPLES E EMPRESÁRIAS EM CASO DE EXERCÍCIO DE ATIVIDADE DISSONANTE COM SEU REGIME JURÍDICO: EFEITOS NA FALÊNCIA, NA RECUPERAÇÃO JUDICIAL E NA INSOLVÊNCIA
}

\author{
Alexandre Ferreira de Assumpção Alves* \\ Mariana Gonçalves Robertson Pinto**
}

\begin{abstract}
RESUMO: O trabalho apresenta reflexões sobre a lacuna regulatória no direito brasileiro para se aferir se o objeto da sociedade é ou não uma empresa quando de seu registro. Embora o Código Civil se refira a "elemento de empresa" no art. 966, na prática, não existe orientação quanto aos critérios de aferição. Analisa-se a insolvência da sociedade formalmente simples, mas materialmente atuante como sociedade empresária, bem como da sociedade formalmente empresária, mas materialmente simples. Aventa-se a hipótese de sujeição aos institutos da falência e da recuperação judicial. Adota-se na elaboração o método dedutivo e pesquisa dos tipos bibliográfica e documental.
\end{abstract}

Palavras-Chave: Empresa; Sociedade; Registro Empresarial; Regulação; Insolvência

\section{THE REGISTRATION REGULATION OF SIMPLE AND ENTREPRENEURIAL COMPANIES IN CASE OF INCOMPATIBILITY BETWEEN THEIR ACTIVITY} AND THEIR LEGAL FRAMEWORK: BANKRUPTCY, JUDICIAL RECOVERY

\section{AND INSOLVENCY EFFECTS}

ABSTRACT: This paper sets out considerations on the existing gap in the Brazilian legislation to assess whether or not the corporation is a entrepreneurial company by the time of its registration. Despite, the Brazilian Civil Code mentions "entrepreneurial element" in its article 966, there is no benchmarks. This work analyzes the insolvency of a entrepreneurial company registered at the Civil Registry of Legal Entities and of a simple or civil company registered at the Commercial Registry. The possibility of their subjection to bankruptcy and judicial recovery is faced. This paper was written using the deductive method as well as literature research.

\footnotetext{
* Mestre e Doutor em Direito. Professor Associado de Direito Empresarial nas Faculdades de Direito da UERJ e da UFRJ. Docente permanente do PPGD da UERJ, linha de pesquisa Empresa e Atividades Econômicas. Endereço eletrônico: alexandrealves@uerj.br

** Mestre em Economia Empresarial pela Universidade Cândido Mendes. Doutoranda em Direito pela Universidade do Estado do Rio de Janeiro - UERJ, na linha de pesquisa denominada Empresa e Atividades Econômicas. Advogada. Endereço eletrônico: mpinto@campinhoadv.com
}

Rev. de Direitos Fundamentais nas Relações do Trabalho, Sociais e Empresariais | e-ISSN: 2525-9903 | Maranhão | v. 3 | n. 2 | 
KeYwORDS: Business; Company; Corporation; Commercial Registry; Regulation; Insolvency.

\section{INTRODUÇÃO}

Em razão do disposto no caput do art. 981 do Código Civil, a exploração de uma atividade econômica com o objetivo de partilha dos resultados daí advindos entre os sócios pode se dar através de uma sociedade simples ou empresária. O caput do art. 982 do mesmo diploma codificado distingue as sociedades, quanto ao objeto, em simples e empresária e, em seu parágrafo único, adota o critério da forma para a definição do regime jurídico, enquadrando como sociedade simples a cooperativa e como empresária as sociedades por ações. A sociedade empresária deve explorar "atividade própria de empresário sujeito a registro" e as sociedades simples, residualmente, outras atividades.

Entretanto, a realização do enquadramento de uma sociedade como simples ou empresária - e o consequente arquivamento de seus atos constitutivos no Registro Civil das Pessoas Jurídicas ou na Junta Comercial, respectivamente - suscita dissenso entre a doutrina e a regulação registral exercida pelo Departamento de Registro Empresarial e Integração (DREI), não se apresentando, em diversas ocasiões, como uma tarefa de simples implementação, mesmo por parte daqueles que estejam de boa-fé e bem informados.

A regulação vinculada ao regime jurídico das sociedades no âmbito do Código Civil é falha, eis que o conceito de sociedade empresária é extraído do de empresário e esse exige a presença do "elemento de empresa" para sua caracterização. Assim, há insegurança jurídica àqueles que desejam explorar uma atividade econômica quando escolhem um tipo societário cujo regime jurídico irá depender do seu objeto, notadamente as sociedades limitadas.

Sob o ponto de vista prático, esta questão é extremamente delicada, na medida em que um equívoco por ocasião deste enquadramento pode trazer consequências graves para a pessoa jurídica e seus sócios em um cenário de insolvência.

O objetivo geral do trabalho é apontar como a ausência de regulação dos órgãos de registro, como efeito da lacuna legislativa, permite que qualquer atividade econômica seja desenvolvida por uma sociedade simples ou por uma sociedade empresária, não havendo qualquer aferição ou comprovação do "elemento de empresa". Em decorrência, é suscitada a 
hipótese de que toda a construção doutrinária, apoiada na teoria da empresa e na influência do direito italiano no Brasil, não se reflete na prática registral. Outro objetivo é levantar, objetivamente, possíveis consequências a serem experimentadas por uma sociedade formalmente simples, pelo fato de seu contrato estar registrado no Registro Civil das Pessoas Jurídicas, mas que exerça materialmente empresa, e vice-versa, diante de uma situação de insolvência. Será possível não decretar a falência ou não conceder recuperação judicial a uma sociedade formalmente empresária, mas cuja atividade seja exercida sem elemento de empresa (v.g. atividade literária), não obstante haja certidão da Junta Comercial? Prevalece o critério substancial (exercício efetivo de empresa) para os fins do art. 985 do Código Civil, de modo a se considerar em comum a sociedade que não faça coincidir os elementos formal e material?

O trabalho adotou em sua elaboração o método dedutivo, partindo da premissa maior que o direito brasileiro adota um sistema dual quanto ao regime jurídico das sociedades, com reflexos, entre outros, nos campos do registro, da execução coletiva e dos meios preventivos à insolvência. Esse sistema dual, ressalvadas as exceções legais, tem como base dogmática a teoria da empresa e, portanto, deveria ser aplicado na regulação do registro empresarial e de pessoas jurídicas (premissa menor). Pretende-se, destarte, concluir se há compatibilidade ou não da regulação com o conceito de empresário e sociedade empresária e a interpretação da doutrina. A pesquisa empregada no artigo foi dos tipos bibliográfica e documental.

\section{O REGIME JURÍDICO DAS SOCIEDADES ANTES DO CÓDIGO CIVIL DE 2002}

Antes do advento do Código Civil de 2002, as sociedades apresentavam-se como comerciais (ou mercantis) e civis, sendo certo que estas últimas podiam ou não ter fins econômicos ou lucrativos. Com a chegada do mencionado diploma, as sociedades passaram necessariamente a contar, ontologicamente, com a finalidade lucrativa e o papel antes desempenhado pelas sociedades civis sem fins econômicos passou a ser exclusivamente exercido pelas associações, espécie distinta de pessoa jurídica de direito privado ${ }^{1}$. Sem

\footnotetext{
${ }^{1}$ No regime jurídico vigente, “constituem-se as associações pela união de pessoas que se organizem para fins não econômicos”, não havendo, entre os associados, direitos e obrigações recíprocos (art. 53 do Código Civil). Por
}

Rev. de Direitos Fundamentais nas Relações do Trabalho, Sociais e Empresariais | e-ISSN: 2525-9903 | Maranhão | v. 3 | n. 2 | 
embargo, permaneceu a distinção quanto ao objeto, só que hodiernamente com os nomen jura sociedade simples e sociedade empresária, nos termos do caput do art. 982 do Código Civil.

No regime jurídico anterior, era assente que o enquadramento das sociedades comerciais se fazia pela forma (sendo comerciais as sociedades anônimas e as sociedades em comandita por ações) e pelo objeto ${ }^{2}$, já que a lei estabelecia a chamada matéria de comércio ou mercancia para a caracterização do objeto do Direito Comercial.

O núcleo inicial dos atos de comércio foi fixado no Regulamento $\mathrm{n}^{\circ} .737 / 1850$ (arts. 19 e 20, jurisdição comercial em razão das pessoas e dos atos), o qual, posteriormente, foi complementado por leis esparsas. Como o Direito é dinâmico, a própria vis attractiva do Direito Comercial se encarregou de abraçar, por exemplo, contratos como o arrendamento mercantil, a representação comercial e a franquia, sob a máxima de que o negócio jurídico atípico deveria ser regido pelo típico mais próximo ${ }^{3}$. Essa mesma vis attractivatambém era invocada para definir como comerciais os atos bifrontes, que eram protagonizados por um comerciante, no exercício direto de sua atividade profissional, e por um não comerciante ${ }^{4}$.

Ainda assim, havia situações que geravam certa insegurança. Ao tratar especificamente do regime das sociedades anteriormente ao Código Civil de 2002, Sérgio Campinho 5 (2013, p. 425-426) salienta que:

outro lado, "celebram contrato de sociedade as pessoas que reciprocamente se obrigam a contribuir, com bens ou serviços, para o exercício de atividade econômica e a partilha, entre si, dos resultados" (caput do art. 981 do Código Civil).

${ }^{2}$ Nesse sentido, Fábio Ulhoa Coelho anota que "quando o ordenamento jurídico brasileiro era filiado ao sistema francês de disciplina privada da economia, fundado na teoria dos atos de comércio (Cap. 1), adotava o conceito de sociedade comercial para a identificação da pessoa jurídica exercente das mais importantes atividades econômicas. Distinguia-a, então, da sociedade civil pela natureza de seu objeto. Sendo este a exploração de negócio definido como ato de comércio, submetia-se a sociedade ao regime próprio do direito comercial (isto é, estava sujeita à falência, podia pleitear concordata, tinha obrigações específicas de escrituração de livros etc.). Se o objeto social, no entanto, não fosse ato de comércio, era civil a sociedade. Tal critério apenas se excepcionava em relação às sociedades por ações, submetidas ao regime comercial em razão apenas da forma, independentemente do objeto (LSA, art. $\left.2^{\circ}, \S 1^{\circ}\right) "(2016$, v. 2 , p. 24).

${ }^{3} \mathrm{O}$ arrendamento mercantil, contrato de natureza jurídica complexa, contempla tanto uma locação de bens móveis, como um financiamento para a sua aquisição, sendo, por isso, disciplinado pelo Direito Comercial, que sempre se ocupou das prefaladas relações jurídicas. A franquia empresarial, por seu turno, se aproxima a uma distribuição de produtos e a uma concessão de uso de marca, contratos sob o pálio do Direito Comercial.

${ }^{4}$ A título exemplificativo, a compra e venda de bens móveis ou semoventes que trazia em um de seus polos um comerciante no exercício direto de sua atividade profissional e, no outro, um não comerciante era considerada compra e venda comercial, sendo, portanto, regida pelo Código Comercial (art. 191). Já a compra e venda protagonizada por comprador e vendedor não comerciantes era considerada civil e disciplinada pelo Código Civil. ${ }^{5}$ Em nota de rodapé, o citado autor ressalva a existência de posições em sentido contrário, como aquela defendida por Rubens Requião, o qual elegia o critério de se determinar o enquadramento pela atividade preponderante contida no objeto (2013, p. 426, nota de rodapé $n^{\circ}$. 4). 
No âmbito societário, as sociedades mercantis eram aquelas constituídas para a prática do comércio. Formavam-se para a prática profissional da mercancia. Diferenciavamse das sociedades civis de fins econômicos em razão do objeto (exploração de atividade econômica compreendida na matéria de comércio) ou da forma (as sociedades por ações, por força de lei, adquiriam a qualidade mercantil em função exclusiva da forma, qualquer que fosse o seu objeto).

Dificuldades ocorriam quando a sociedade apresentava objeto misto, ou seja, reunindo concomitantemente atividades mercantil e civil. Mas, nessas situações, ganhava corpo a ideia de que a sociedade deveria ser enquadrada como comercial, pela especialidade do Direito Comercial.

A guisa de ilustração, insegurança também acompanhava as sociedades de consórcio. Em verdade, ao facultar o exercício de tal atividade às pessoas jurídicas que exercessem "atividade comercial, industrial ou de compra e venda de bens imóveis", o $§ 1^{\circ}$ do art. $1^{\circ}$ da Lei $n^{\circ}$. 5.768/71 permitia que sua exploração fosse feita tanto por sociedades mercantis, quanto por sociedades civis com fins econômicos voltadas para a compra e venda de bens imóveis. Ademais, à luz do art. 17 da Lei $\mathrm{n}^{\circ}$. 4.595/64, formou-se o entendimento de que as sociedades de consórcio se caracterizavam como instituições financeiras, restando, assim, submetidas ao regime da Lei $n^{\circ}$. 6.024/74, que contempla a possibilidade de falência das mencionadas instituições no curso da liquidação extrajudicial ou se inviável essa (art. 12, $d$; e art. 19, d). Diante disso, surgiam as seguintes indagações na vigência do $1^{\circ}$ Código Civil: (i) em caso de falência de uma sociedade civil de consórcio com fim econômico, seus sócios responderiam de forma solidária e ilimitada pelas obrigações sociais? (ii) considerando que esta sociedade não possuiria escrituração mercantil, responderiam eles por crime falimentar? Essas questões se colocavam, porquanto a própria lei dava aos sócios o direito de optarem pela roupagem de sociedade comercial ou civil com fim econômico.

$\mathrm{O}$ regime anterior ao Código Civil vigente não conferia plena segurança jurídica. Todavia, como será demonstrado ao longo do item subsequente, o quadro dos dias de hoje é ainda mais delicado, pois não se tem sequer como afirmar que exista um consenso no sentido de que o enquadramento de uma sociedade, como simples ou como empresária, se dê em função da forma e do objeto. 


\section{O REGIME JURÍDICO DAS SOCIEDADES NO CÓDIGO CIVIL DE 2002}

Fundamentais para a definição dos critérios de classificação de uma sociedade como simples ou empresária são os arts. 966 e 982 do Código Civil. ${ }^{6}$

Com base nestes dois dispositivos, há em doutrina posicionamentos distintos quanto ao enquadramento de uma sociedade como simples ou empresária, a saber: se a natureza simples ou empresária da sociedade ocorre em função do (i)modo de a sociedade exercer a sua atividade econômica; ou (ii)nível de organização; ou, ainda, (iii) objeto.

Jorge Lobo sustenta que a distinção se dá justamente em função do "modo de a sociedade exercer a atividade econômica para a qual foi constituída" (2004, p. 13) 7 .

\footnotetext{
${ }^{6}$ Art. 966. Considera-se empresário quem exerce profissionalmente atividade econômica organizada para a produção ou a circulação de bens ou de serviços.

Parágrafo único. Não se considera empresário quem exerce profissão intelectual, de natureza científica, literária ou artística, ainda com o concurso de auxiliares ou colaboradores, salvo se o exercício da profissão constituir elemento de empresa.

Art. 982. Salvo as exceções expressas, considera-se empresária a sociedade que tem por objeto o exercício de atividade própria de empresário sujeito a registro (art. 967); e, simples, as demais.

Parágrafo único. Independentemente de seu objeto, considera-se empresária a sociedade por ações; e, simples, a cooperativa.

${ }^{7} \mathrm{O}$ referido autor se vale das seguintes palavras para apresentar o seu entendimento: "Em razão do modo de exercerem suas atividades, as sociedades classificam-se em empresárias e simples. [...] São empresárias as sociedades organizadas profissionalmente como unidades econômicas de produção ou circulação de bens ou de serviços (CCivil, arts. 966, 967, 981 e 982). As anônimas ou companhias são sociedades empresárias, independentemente de seu objeto (CCivil, art. 982, par. único, e LSA, art. $2^{\circ}, \S 1^{\circ}$ ). [...] São simples as sociedades que, embora tenham por objeto o exercício de atividade econômica de produção ou circulação de bens ou de serviços, não se organizam em empresa (CCivil, art. 982, parte final)" (2004, p. 10-11). Na sequência, após apresentar questionamentos que traduzem a controvérsia e reproduzir um verdadeiro compilado de posições sobre o tema, o aludido autor destaca: "Para mim, fiel aos arts. 982 c/c 966, do Código Civil, a distinção entre sociedade empresária e sociedade simples não se baseia nem no Direito Comparado, nem na dicotomia entre atos de comércio e atos civis, nem no objeto social, nem na finalidade lucrativa, mas no modo de a sociedade exercer a atividade econômica para a qual foi constituída" (2004, p. 13). Por fim, arremata: "O Código Civil, ao cuidar das pessoas jurídicas de direito privado, classifica-as em associações, sociedades e fundações (art. 44, I a III), constituindo-se as "associações pela união de pessoas que se organizam para fins não econômicos" (art. 53, caput) e as sociedades, para "o exercício da atividade econômica" (art. 981), ainda que "a atividade" se restrinja "à realização de um ou mais negócios determinados" (art. 981, par. único), o que me autoriza a afirmar: $\left(1^{\circ}\right)$ a distinção entre sociedade empresária e sociedade simples não repousa: (a) nem no objeto social, portanto tanto a sociedade empresária quanto a sociedade simples têm por objeto "o exercício de atividade econômica" (art. 981) de produção ou circulação de bens ou de serviços (art. 966), "própria do empresário sujeito a registro" (art. 982); (b) nem na natureza dos atos que praticam - ato civil ou ato comercial - abolidos pelo Código Civil; (c) nem na finalidade lucrativa, pois ambas visam auferir lucros; $\left(2^{\circ}\right)$ a sociedade simples, ao surgir, entre nós, no Anteprojeto de Código de Obrigações, era, apenas e exclusivamente, um "tipo", uma "forma" de sociedade, passando, no Anteprojeto de Código Civil de 1974, a ser, além de um "tipo" ou "forma" de sociedade, um modo de organizar-se a atividade econômica de produção ou circulação de bens ou de serviços; $\left(3^{\circ}\right)$ o Código Civil, na esteira do Anteprojeto de Código Civil de 1974 e do Projeto de Código Civil de 1975, abandonou não somente a tradição do nosso Direito Comercial, que dividia as sociedades em comerciais e civis, como, por igual, afastou-se da sistemática do Anteprojeto de Código de Obrigações, substituindo a expressão sociedade comercial por sociedade empresária e sociedade civil por sociedade simples, distinguindo-as, todavia, não em função do objeto social, mas pelo modo de exercerem suas atividades; $\left(4^{\circ}\right)$ por conseguinte, a distinção entre sociedade empresária e sociedade simples
} 
José Edwaldo Tavares Borba, por sua vez, considera que a classificação das sociedades em simples e empresária "decorre da natureza da sociedade, segundo a dinâmica de sua atividade" e objetivamente anota: "atividade econômica organizada - sociedade empresária; atividade econômica não organizada - sociedade simples" (2015, p. 11). Adiante, destaca que, "no universo societário, se não se delineia a organização, a hipótese é de sociedade simples; presente a organização, configura-se a sociedade empresária” (BORBA, 2015, p. 21$)^{8}$.

Ricardo Negrão (2003, v. 1, p. 237)declina a sua posição nos seguintes moldes:

Em relação à atividade desenvolvida, as sociedades se classificam em: (1) empresárias, as que exercem atividade econômica organizada para a produção ou a circulação de bens ou serviços; e (2) simples, todas as demais, isto é, as que, embora

fundamenta-se no modo pelo qual a atividade econômica é exercida: se a sociedade se organiza profissionalmente como uma unidade econômica de produção ou circulação de bens ou de serviços, é empresária; se não, é sociedade simples" (2004, p. 19-20).

${ }^{8}$ Cabe reproduzir na íntegra o tópico denominado "Sociedades simples e sociedades empresárias. Profissionais autônomos e empresários individuais": "As sociedades simples são as que não dispõem de uma estrutura organizacional e as que, mesmo dispondo, dedicam-se a atividades intelectuais ou a atividades rurais (agricultura e pecuária), cabendo registrá-las no Registro Civil das Pessoas Jurídicas. As sociedades empresárias são as que exercem atividades próprias de empresário (art. 982), inclusive a sociedade dedicada a atividade rural, contanto que se inscreva no Registro Público de Empresas Mercantis (art. 984). Pode-se, por conseguinte, afirmar que o direito brasileiro adotou a teoria da empresa, embora mitigando-a, a exemplo do direito italiano, mediante concessões aos interesses dos empresários rurais, resquícios dos privilégios do senhor feudal, que o direito comercial havia preservado. No campo da atividade econômica, exercida profissionalmente para a produção de bens ou serviços, tem-se portanto a figura do profissional autônomo, que trabalha de forma pessoal, e tem-se o empresário individual, este contando com uma organização de pessoas ou bens materiais. No universo societário, se não se delineia a organização, a hipótese é de sociedade simples; presente a organização, configura-se a sociedade empresária. As exceções a serem consideradas, inclusive no plano societário, onde seriam sociedades simples, concernem ao trabalho intelectual, que não tem natureza empresarial, e à atividade rural, que poderá ser empresária ou não, de acordo com o registro" (2015, p. 20-21). Na sequência, ao tratar do "sistema de registro", Tavares Borba retorna ao tema da classificação e salienta: "O enquadramento da sociedade como empresária depende (art. 982) de dois fatores: (a) exercício de atividade própria de empresário, que é a atividade econômica organizada; e (b) não incidência das 'exceções expressas', que são as relativas ao trabalho intelectual, e, por opção, à atividade rural. $\mathrm{O}$ enquadramento como sociedade simples ocorre por exclusão. Se a sociedade não é empresária, a sua condição é de sociedade simples. Esse enquadramento só é rigoroso em suas posições extremas, isso porque não mais persistem as diferenças do passado, quando existiam, para as sociedades, dois códigos e dois estatutos jurídicos inteiramente díspares. Hoje, com a convergência dos regimes, a diversidade de registros condiciona efeitos bastante limitados, e que se resumem ao maior ou menor rigor a que se submetem. A divisão (simples/empresária) é de natureza técnica, e tem sentido funcional, de modo a tornar mais complexa a vida do empresário e mais simples a vida do não empresário. Essa separação coloca em uma das posições extremas as sociedades por ações, que, por uma presunção legal absoluta (iuris et de iure), serão sempre empresárias. É que a sociedade anônima e a sociedade em comandita por ações detêm uma estrutura jurídica destinada aos grandes negócios, complexos por si mesmos. Serão empresárias por força de lei. Na outra posição extrema encontra-se a sociedade simples stricto sensu que, por adotar uma forma exclusiva de sociedade simples, não poderá desenvolver atividades próprias de sociedade empresária, salvo se estas se enquadrarem nas exceções legais (atividades intelectuais ou rurais). As sociedades em nome coletivo, em comandita simples e limitadas tanto poderão ser simples como empresárias, e, para esse efeito, deve-se indagar a respeito da estrutura organizacional" (2015, p. 21-22). 
pratiquem atividade econômica, não desenvolvem objeto próprio das empresárias (art. 982).

No tópico subsequente, o aludido autor (NEGRÃO, 2003, v. 1, p. 238) salienta que "considerando, ainda, a natureza da atividade econômica desenvolvida, as sociedades podem ser empresárias por força de lei (art. 982) e empresárias por equiparação (art. 984), constituindo estas as que tenham por objeto o exercício de atividade rural".

Sérgio Campinho, por seu turno, defende que a classificação de uma sociedade como simples ou empresária se dá em função de seu objeto ou da forma adotada (2016, p. 49-51)9 .

Nesse mesmo curso, é o escólio de Gustavo Tepedino, Heloisa Helena Barboza, Maria

Celina Bodin de Moraes et al., cabendo, aqui, transcrever suas palavras (2011, v. III, p. 43):

1. Classificação consoante o objeto social. O dispositivo preserva o critério tradicional no direito brasileiro, ao adotar o objeto da sociedade como elemento distintivo entre sociedade simples e empresária. O discrime, no entanto, não mais se baseia nos atos de comércio, mas no exercício de atividade empresarial pela sociedade, corroborando, de forma definitiva, a teoria da empresa. Dessa forma, salvo previsões legais específicas, toda sociedade cujo objetivo se traduz no exercício profissional de atividade econômica organizada para a produção ou circulação de bens ou de serviços possuirá natureza empresária. Do mesmo modo, consideram-se simples as sociedades que reunirem profissionais liberais, artistas, cientistas, literatos, sem agregar elemento de empresa, nos termos do par. ún. do art. 966. Estas podem adotar forma de sociedade simples ou qualquer outro tipo, sem que com isto se altere a natureza não empresária do empreendimento, exceto quando se organizem sob a forma de sociedades anônimas ou em comandita por ações, às quais atribui a lei natureza empresária independentemente de seu objeto.

\footnotetext{
${ }^{9}$ Eis as suas palavras: "Em função do seu objeto ou da forma societária adotada, as sociedades podem ser de duas espécies: empresária ou simples. A sociedade empresária é aquela que tem por objeto a exploração habitual de atividade econômica organizada para a produção ou a circulação de bens ou de serviços, sempre com o escopo de lucro. Explora, pois, de forma profissional a empresa, resultado da ordenação do trabalho, capital e, porque não, tecnologia. A sociedade simples, ao revés do que afoitamente se possa pensar, também executa atividade econômica, e seus integrantes partilham, entre si, os resultados que venham a ser auferidos. Se assim não o fosse, não seria sociedade. A exploração de atividade econômica e a partilha dos lucros são próprias do conceito sociedade. A sociedade simples, segundo o perfil legislativo que lhe foi destinado, empreende atividades econômicas específicas. O ordenamento jurídico positivo é quem lhe reserva o objeto. Algumas antigas sociedades civis com fins econômicos se enquadram como sociedade simples, por força, repita-se, de reserva expressa do ordenamento jurídico positivo. São exemplos de sociedades simples: as cooperativas (Código Civil, parágrafo único do art. 982), certas sociedades dedicadas à atividade agrícola ou pastoril (não se enquadrando aqui as indústrias agrícolas, porquanto a atividade de transformação, própria da indústria, já lhes confere a condição de sociedade empresária) e as sociedades de advogados (parágrafo único do art. 966 do Código Civil c/c arts. 15 e 16 da Lei $\left.\mathrm{n}^{\circ} .8 .906 / 94\right)$. As sociedades empresárias abrigam as antigas sociedades comerciais e inúmeras das antigas sociedades civis de fim econômico. Assim, por exemplo, são sociedades empresárias as agências de viagens, os hospitais, as casas de saúde, as administradoras de imóveis e condomínios que no direito anterior se enquadravam como sociedades civis. Em resumo, simples serão as sociedades que adotarem forma de cooperativa ou que exercerem objeto atinente à atividade própria de empresário rural ou executarem atividades definidas por lei como não empresariais, como as localizadas no parágrafo único do art. 966 do Código de 2002” (2016, p. 49-51).
} 


\section{A REGULAÇÃO REGISTRAL DAS SOCIEDADES SIMPLES E EMPRESÁRIAS EM CASO DE EXERCíCIO DE ATIVIDADE DISSONANTE COM SEU REGIME JURÍDICO: EFEITOS NA FALÊNCIA, NA \\ RECUPERAÇÃO JUDICIAL E NA INSOLVÊNCIA}

Considerando que o caput do art. 982 do Código Civil preconiza "considera-se empresária a sociedade que tem por objeto o exercício de atividade própria de empresário sujeito a registro"; e, ainda, que o caput do art. 966 do mesmo diploma estabelece que “considera-se empresário quem exerce profissionalmente atividade econômica organizada para a produção ou a circulação de bens ou de serviçoo" pode-se afirmar que as sociedades simples exercem atividade econômica não organizada? Caso positivo, quais seriam os parâmetros para se aferir a organização caracterizadora das sociedades empresárias ou a ausência dessa organização caracterizadora das sociedades simples? No mais, como se poderia avaliar o modo pelo qual a atividade é exercida?

Adianta-se que não se encontra nos dispositivos legais supra do Código Civil parâmetros para identificar elemento de empresa, tampouco quando uma atividade intelectual passa a reunir esse elemento para tornar a pessoa empresária e sujeita-la ao registro empresarial compulsoriamente (art. 966, parágrafo único). Essa lacuna interfere diretamente na distinção entre sociedade simples e empresária, eis que o art. 982 tem remissão ao art. 967, que trata da obrigatoriedade da inscrição do empresário. Nota-se que o legislador, embora tenha dogmaticamente adotado a teoria da empresa, deixou em aberto a organização da atividade econômica na caracterização de empresário e, por extensão, na de sociedade empresária.

Se, por outro lado, for considerado que o enquadramento não é ditado pela existência ou não de organização no exercício da atividade, mas sim pelo próprio objeto (expressamente mencionado no caput do art. 982), chegando-se (à luz do próprio parágrafo único do referido art. 966) às sociedades simples por exclusão e retornando-se às empresárias por meio da ressalva "salvo se o exercício da profissão constituir elemento de empresa", caberá indagar: em que momento o "elemento de empresa" passa a existir?

Quando estamos diante de um hospital ou de uma casa de saúde, que possui uma marca, um título de estabelecimento, que conta com uma série de sócios que sequer são médicos, que terceiriza o CTI ou o ambulatório, por exemplo, não se tem qualquer dúvida em relação ao fato de que esta sociedade é uma sociedade empresária. Todavia, essa discussão ganha relevo quando não se está diante de situações extremas.

Possivelmente, a apresentação de um exemplo contribuirá para o desfecho da linha de raciocínio que se pretende estabelecer. Imagine-se uma sociedade constituída por três

Rev. de Direitos Fundamentais nas Relações do Trabalho, Sociais e Empresariais | e-ISSN: 2525-9903 | Maranhão | v. 3 | n. 2 |

p. $108-130$ | Jul/Dez. 2017. 
cardiologistas que cuidam pessoalmente de seus pacientes com o auxílio de uma secretária. Caberia investigar o seu grau de organização ou o modo pelo qual eles exercem a atividade? O que denotaria haver organização ou falta dela? Superada essa etapa ou até mesmo esse critério de enquadramento e considerando estar-se diante do exercício de profissão intelectual de natureza científica, estaríamos diante de uma sociedade simples? Caso positivo, em que condições essa caracterização poderia sucumbir diante do tal "elemento de empresa"? A contratação de um designer e a elaboração de uma logo que passa a ser usada no timbrado dos cardiologistas e até mesmo a concepção de um site moderno já caracterizariam aquela sociedade de cardiologistas como uma sociedade empresária? O "elemento de empresa" já estaria presente?

A posição da holding pura, entendida como a sociedade que se dedica exclusivamente a titularizar quotas ou ações de outras sociedades, também gera indagações. Seria ela uma sociedade simples ou empresária? A questão se agrava quando, ao menos no Estado do Rio de Janeiro, tanto o Registro Civil das Pessoas Jurídicas como a Junta Comercial recebem seu ato constitutivo independente da análise do objeto e do modo como é exercido. Em ultima ratio, como fica a situação daqueles que querem constituir uma holding pura diante do fato de que a aquisição de personalidade jurídica depende da inscrição, no registro próprio, do ato constitutivo, a teor do art. 985 do Código Civil? E a falta de há previsão que o registro putativo em órgão incompetente livraria a sociedade do status de "sociedade em comum".

Através das indagações até então formuladas, pretende-se demonstrar que em muitas situações não será singela a missão de enquadrar uma determinada sociedade como simples ou empresária. Transcende ao objeto deste trabalho defender um ou outro critério de classificação, embora em todos se vislumbre a importância do modo de exercício da atividade, ou seja, com organização e não apenas o ato em si. Na realidade, o panorama apresentado teve o exclusivo escopo de demonstrar que, em determinadas situações, pessoas bem informadas e de boa-fé terão dificuldades em realizar o aludido enquadramento. $\mathrm{O}$ cometimento de um equívoco em relação à realização ou à manutenção do registro de uma sociedade poderá trazer aos seus sócios graves consequências.

Há três pontos que separam as sociedades simples das empresárias: a escrituração, o registro e o regime da insolvência. No que tange especificamente à escrituração, as sociedades empresárias precisam observar o disposto nos arts. 1.179 e seguintes do Código Civil, além das normas fiscais e contábeis que se aplicam a ambas as espécies societárias. Quanto ao registro, 
as sociedades empresárias devem ter seus atos arquivados na Junta Comercial e as simples no Registro Civil das Pessoas Jurídicas (art. 1.150 do Código Civil). No que se refere ao regime da insolvência, as sociedades empresárias se submetem à Lei $\mathrm{n}^{\circ}$. 11.101/2005 e as simples se sujeitam ao procedimento de insolvência civil (art. 786 do Código de Processo Civil de1973), cujas regras de direito material estão no Código Civil (arts. 955 a 965 -Das Preferências e Privilégios Creditórios) e as de direito processual no Código de Processo Civil de 1973, mantidas em vigor por força do disposto no art. 1.052 do Código de Processo Civil de 2015.

\section{A REPERCUSSÃo DA FALTA DE CRITÉRIO PARA DEFINIR O ELEMENTO DE EMPRESA NO REGISTRO DA SOCIEDADE}

Cumpre examinar a repercussão no âmbito registral da inexistência de critérios legais para aferição do "elemento de empresa" ou da organização da atividade econômica para fins da caracterização de uma sociedade como simples ou empresária. Tampouco as normas administrativas fornecem qualquer segurança aos agentes regulados, haja vista a amplíssima aceitação de quaisquer atividades econômicas, até mesmo aqueles que se subentendem fora do âmbito do direito empresarial.

A análise partirá da premissa de que, no momento do registro, há boa-fé do administrador da sociedade, não se pretendendo mascarar o exercício de atividades próprias de empresário ou próprias de não empresário.

O direito brasileiro ainda não superou a dualidade de registros para as sociedades. Houve avanço relativo para unificação de tratamento, como a possibilidade de sociedades simples aderirem ao Simples Nacional (art. $3^{\text {o }}$ da Lei Complementar $n^{\circ}$. 123/2006), enquadrando-se como microempresa ou empresa de pequeno porte, mesmo sem exercer empresa. Todavia, o art. 1.150 do Código Civil é peremptório: a sociedade empresária vinculase ao Registro Empresarial e a sociedade simples ao Registro Civil das Pessoas Jurídicas. Se a sociedade simples adotar um dos tipos empresariais, o RCPJ deverá seguir as normas administrativas do Registro Empresarial, além das disposições da Lei nº. 6.015/73, no que couber.

Rev. de Direitos Fundamentais nas Relações do Trabalho, Sociais e Empresariais | e-ISSN: 2525-9903 | Maranhão | v. 3 | n. 2 | 
O Registro Empresarial é disciplinado pela Lei $n^{\circ}$. 8.934/94, regulamentada pelo Decreto $n^{\circ}$. 1.800/96. A regulação dos serviços de registro e dos atos a ele associados incumbia ao Departamento Nacional de Registro do Comércio (DNRC), criado em 1961, pela Lei $n^{\circ}$. 4.048, e extinto pelo Decreto $n^{\circ}$. 8.001/2013. Atualmente, por força do art. $8^{\circ}$, inciso VI, do Anexo I, desse Decreto, como sucessor do DNRC, o Departamento de Registro Empresarial e Integração (DREI) é o órgão da administração pública federal responsável por "estabelecer normas procedimentais de arquivamento de atos de firmas mercantis individuais e sociedades mercantis de qualquer natureza", com base no art. $4^{\circ}$, inciso VI, da Lei nº 8.934/94.

Com base no dispositivo legal supra, o DREI elabora Instruções Normativas, vinculantes no plano técnico às Juntas Comerciais (art. $6^{\circ}$ da Lei $n^{\circ}$ 8.934/94) e para o Registro Civil das Pessoas Jurídicas quando a sociedade simples adotar tipo empresarial. A IN n ${ }^{\circ}$. 38, de 02.03.2017, aprovou os Manuais de Atos de Registro e suas Alterações (Anexos).

Nos manuais que interessam ao âmbito deste artigo - Sociedade Limitada e Empresa Individual de Responsabilidade Limitada (Anexos II e V, respectivamente) - por se tratarem de sociedades que podem atuar com ou sem exercício de empresa, não há nenhuma menção a elemento de empresa. Tampouco estão presentes critérios para se aferir se o objeto informado pelo requerente do registro será exercido de modo organizado, ou seja, como empresa.

No caso do registro de sociedade limitada, prevê o item 1.2.12 do Anexo II quanto ao objeto social, que esse não poderá ser ilícito, impossível, indeterminado ou indeterminável, ou contrário aos bons costumes, à ordem pública ou à moral ${ }^{10}$. A segunda e última vedação ao registro refere-se à sociedade cujo objeto inclua atividade de advocacia, por força do art. 15, $\S 1^{\circ}$, da Lei ${ }^{\circ} 8.906 / 94$. A única exigência formal quanto ao objeto é sua inclusão no contrato social, com indicação precisa e clara das atividades a serem desenvolvidas pela sociedade.

Da mesma forma, para o registro de EIRELI, as mesmas vedações e obrigatoriedade quanto ao objeto social estão previstas (item 1.2.11 do Anexo V).

O requerente do registro deverá indicar apenas a(s) atividade(s) da futura sociedade, estando excluída somente a advocacia. As demais, sendo lícitas, possíveis e determinadas precisamente (gênero e atividade) poderão ser exercidas, mesmo que não sejam empresas.

\footnotetext{
${ }^{10}$ Igual vedação está presente no art. 115 da Lei de Registros Públicos (Lei $n^{\circ}$. 6.015/73): "Não poderão ser registrados os atos constitutivos de pessoas jurídicas, quando o seu objeto ou circunstâncias relevantes indiquem destino ou atividades ilícitos ou contrários, nocivos ou perigosos ao bem público, à segurança do Estado e da coletividade, à ordem pública ou social, à moral e aos bons costumes”.
} 
É evidente que o Registro Empresarial admite o arquivamento de atos de sociedades simples, a despeito do critério do caput do art. 982 do Código Civil, pois nenhum controle do objeto é feito, salvo quanto à sua licitude. O requerente, ainda que de boa-fé, assume os riscos de eventual questionamento quanto a inadequação do registro às determinações do Código Civil, consoante a teoria da empresa, não adotada na regulação registral. Nota-se que a regulação (ou sua ausência quanto ao "elemento de empresa") do DREI, associada ao teor do art. 985 do Código Civil, fornece muito mais insegurança jurídica do que segurança, na medida em que não impede questionamentos futuros, sobretudo em juízo, quanto a eventual condição de sociedade em comum, não personificada, pela irregularidade material do registro.

É importante mencionar que o DREI adota para fins de registro apenas a Classificação Nacional de Atividades Econômicas - CNAE. Os aludidos Anexos II e V (Manuais de Registro) permitem que, opcionalmente, o requerente descreva o objeto por meio de código integrante da estrutura da CNAE.

A CNAE é a classificação oficial adotada pelo Sistema Estatístico Nacional do Brasil e pelos órgãos federais, estaduais e municipais gestores de registros administrativos. O objetivo é padronizar nacionalmente os códigos de atividade econômica e os critérios de enquadramento utilizados pelos diversos órgãos da Administração Tributária. Foi instituída pela Resolução n ${ }^{\circ}$. 54, de 19.12.1994, da Presidência do IBGE, e passou a ser implementada a partir de 1995.

A CNAE tem como referência a Classificação Industrial Internacional Padrão de Todas as Atividades Econômicas, elaborada pela ONU (International Standard Industrial Classification of All Economic Activities - ISIC). Sua gestão e manutenção são de responsabilidade do IBGE, a partir das deliberações da Comissão Nacional de Classificação CONCLA, criada em 1994 pelo Decreto $n^{\circ}$. 1.264/1994). Atualmente é adotada a CNAE 2.0, aprovada pela Resolução CONCLA n ${ }^{\circ}$.1, de 04.09.2006, no uso de sua competência decorrente do art. $2^{\circ}$, inciso III, do Decreto $n^{\circ} .3 .500 / 2000 .^{11}$

\footnotetext{
${ }^{11}$ A partir da CNAE foram derivadas mais duas outras classificações, a CNAE-Fiscal e a CNAE-Domiciliar. A CNAE-Fiscal é um detalhamento das classes da CNAE para uso na administração pública tributária, como por exemplo no registro do CNPJ, que é obrigatório para toda pessoa jurídica. Uma pessoa jurídica de qualquer natureza jurídica pode ter uma ou várias atividades econômicas, derivadas ou não da atividade principal. A CNAEDomiciliar, que na maioria dos casos agrupou classes da CNAE, foi desenvolvida para ser utilizada no censo demográfico e em outras pesquisas domiciliares.
} 
A CNAE não possui qualquer referência quanto ao modo de exercício da atividade econômica. Serviços domésticos, por exemplo, podem ser declarados como objeto de uma sociedade empresária pela CNAE (classe 9700-5), bem como atividades de organizações associativas patronais, empresariais e profissionais, organizações sindicais, associações de defesa de direitos sociais (grupos 941, 942 e 943), todas elas sequer com natureza de sociedade. E se não houver nenhum código específico, poderá ainda o requerente se valer de "outras atividades de serviços pessoais não especificada anteriormente" (classe 9609-2/99).

Além da repercussão negativa na seara da regulação do registro, a carência de uma positivação do que seja elemento de empresa ou organização da atividade econômica pode ter reflexos na sujeição ou não de sociedades empresárias ou simples à falência e à recuperação judicial, temas que serão perscrutados nos itens seguintes.

\section{A INSOLVÊNCIA DA SOCIEDADE FORMALMENTE SIMPLES E MATERIALMENTE EMPRESÁRIA}

Como já afirmado, as sociedades simples não estão sujeitas à falência e sim ao procedimento de insolvência civil, regulado nos arts. 748 a 786-A do Código de Processo Civil de 1973, em função do teor do art. 1.052 do Código de Processo Civil de 2015. Ademais, não podem requerer recuperação judicial, na medida em que este instituto também é reservado aos empresários e às sociedades empresárias (art. $1^{\text {o }}$ da Lei ${ }^{\circ}$. 11.101/2005).

A seguir será exposto de que modo ou em que medida as sociedades formalmente simples (registradas no Registro Civil das Pessoas Jurídicas), mas materialmente empresárias, poderiam ser submetidas aos institutos da falência e da recuperação judicial.

\subsection{A sociedade formalmente simples e materialmente empresária e sua sujeição à falência}

O registro do empresário é declaratório e não constitutivo de sua condição. Nas palavras de Sérgio Campinho (2016, p. 41):

$\mathrm{O}$ arquivamento dos atos constitutivos das firmas individuais ou das sociedades na Junta Comercial não assegura, pelo só efeito do registro, a condição de empresário que se verifica pelo exercício profissional da atividade que lhe é própria, tal qual definida no art. 966.

Rev. de Direitos Fundamentais nas Relações do Trabalho, Sociais e Empresariais | e-ISSN: 2525-9903 | Maranhão | v. 3 | n. 2 | p. 108 - 130 | Jul/Dez. 2017. 
Dessa feita, não é o registro na Junta Comercial que faz com que uma determinada sociedade seja empresária e, a contrario sensu, não é o registro no Registro Civil das Pessoas Jurídicas que a qualifica como simples. Cria-se apenas uma presunção juris tantum.

Ampliando esse raciocínio, tem-se que uma sociedade registrada no Registro Civil das Pessoas Jurídicas - e, portanto, formalmente simples - que exerça nitidamente uma atividade própria de empresário pode ser considerada uma sociedade irregular. A irregularidade decorrerá do fato de a sociedade ser materialmente empresária, mas não estar registrada na Junta Comercial, e sim no Registro Civil das Pessoas Jurídicas. Tal irregularidade não seria apenas de cunho administrativo, mas atingiria também a própria personalidade da sociedade simples, na medida em que um dos requisitos para a aquisição da personalidade jurídica é o arquivamento no registro próprio de seus atos constitutivos. Esse registro deve ser feito no Registro Civil das Pessoas Jurídicas e não na Junta Comercial, a teor dos arts. 985 e 1.150 do Código Civil.

Desse modo, como não há previsão de registro putativo para manter a personalidade jurídica em caso de irregularidade do arquivamento, a sociedade simples seria de direito uma sociedade em comum, submetida às disposições dos arts. 986 a 990 do Código Civil. Por força desse último artigo, todos os sócios responderão "solidária e ilimitadamente pelas obrigações sociais" ${ }^{12}$. E mais: a falência de sociedade com esse perfil acarretará a falência de seus sócios, equiparados ao falido, à luz do disposto nos arts. 81 e 190 da Lei no. 11.101/2005.

O Tribunal de Justiça do Estado do Rio de Janeiro enfrentou a questão em 2010, no julgamento do Recurso de Apelação nº 0106837-38.2004.8.19.0001. Os desembargadores integrantes da $9^{\text {a }}$ Câmara Cível proferiram, à unanimidade, acórdão assim ementado:

\begin{abstract}
Apelação Cível. Pedido de falência. Prestação de serviço médico. Atividade empresarial. Reconhecimento. Sociedade irregular. Falta de registro na Junta Comercial do Estado do Rio de Janeiro. Reforma da decisão. Decretação da falência com reconhecimento da responsabilidade solidária e ilimitada dos sócios. Recurso provido (Recurso de Apelação Cível nº. 0106837-38.2004.8.19.0001, Relator Desembargador Carlos Eduardo Moreira da Silva, julgado à unanimidade pelos integrantes da $9^{\text {a }}$ Câmara Cível do Tribunal de Justiça do Estado do Rio de Janeiro, em 05.10.2010).
\end{abstract}

\footnotetext{
${ }^{12} \mathrm{O}$ art. 990 do Código Civil ainda estabelece que resta excluído do benefício de ordem, contemplado no art. 1.024 do mesmo diploma, aquele que contratou pela sociedade.
} 
Em seu voto, o desembargador relator Carlos Eduardo Moreira da Silva asseverou:

Analisando detidamente os autos, verifica-se que a questão refere-se à condição de sociedade empresária da apelada.

A MM ${ }^{a}$ Juíza de $1^{\circ}$ grau entendeu não ser a apelada,sociedade empresária, tendo em vista não possuir os requisitos para sua caracterização presentes no art. 966 do Código Civil.

No entanto, analisando os atos constitutivos, verifica-se presente a organização de administração, retirada de pró-labore, distribuição de lucros e rateio das despesas, além de evidente exercício de atividade econômica de forma organizada para a produção de serviços na área da saúde.

A atividade exercida pela apelada não se enquadra na exceção prevista no parágrafo único do art. 966 do Código Civil. O fato de ser formada exclusivamente por profissionais da área da saúde, não afastando a caracterização do "elemento de empresa".

Além do mais, quando teve oportunidade de se manifestar, a apelada não manifestou no sentido de ser sociedade simples, tendo apenas feito menção à alteração do quadro societário.

[...]

Desta forma, reconhecendo o caráter empresarial da atividade, analisando não a atividade exercida e sim a forma que é realizada, conclui-se com a aplicação da legislação falimentar.

Devidamente citada, a apelada se quedou inerte, não apresentando razões que justificasse o débito, nem efetuou o depósito elisivo.

Assim, não cabe alternativa senão a decretação da falência da sociedade empresária SMILSERVIÇOS MÉDICOS INFANTIL LTDA., em razão do não cumprimento das obrigações assumidas e representadas pelas duplicatas mercantis que instruíram a inicial.

Quanto à inscrição da sociedade apelada na Junta Comercial do Estado do Rio de Janeiro, de acordo com o art. 2.031 do Código Civil, as sociedades empresárias que não se estariam em conformidade com a legislação deveriam se adequar até 11 de janeiro de 2007. Ultrapassado o prazo, passariam a serem consideradas sociedades irregulares.

Assim, não se adequando à legislação pertinente, pois continuou registrada no Registro Civil de Pessoas Jurídicas, não procedendo ao registro junto ao Registro Público de Empresas Mercantis, impõe-se responsabilidade solidária e ilimitada dos sócios.

Ao reformar a decisão proferida em primeira instância, o desembargador relator, "analisando os atos constitutivos" da sociedade, verificou "presente a organização de administração, retirada de pró-labore, distribuição de lucros e rateio das despesas, além de evidente exercício de atividade econômica de forma organizada para a produção de serviços na área da saúde" e culminou por reconhecer "o caráter empresarial da atividade, analisando não a atividade exercida e sim a forma que é realizada", concluindo pela "aplicação da legislação falimentar".

Neste caso concreto, a delicadeza reside justamente na análise dos critérios que levaram o julgador a enquadrar a sociedade como empresária. É possível aferir a existência de organização através de simples análise do contrato social? E mais: a existência de "organização de administração" e o fato de os administradores receberem pro labore e de haver a distribuição 
de lucros e rateio de despesas podem ser invocados para caracterizar uma sociedade como empresária e afastá-la da espécie simples?

Nota-se também que o Registro Civil das Pessoas Jurídicas não negou o registro ao contrato, limitando-se a verificar se o objeto era lícito, porque está obrigado a observar as normas do registro empresarial quando a sociedade simples adotar tipo de sociedade empresária (no caso do tipo limitada), por força da determinação do art. 1.150, in fine, do Código Civil. Como já examinado no item 4, a regulação do registro empresarial não contém nenhum critério para aferir o modo de exploração do objeto, limitando-se a aceitar qualquer objeto apresentado pelo requerente desde que seja lícito, possível, determinado (preciso) ou determinável, conforme aos bons costumes, à ordem pública ou à moral.

Independentemente dos possíveis equívocos cometidos nas razões de decidir - como, por exemplo, o apontamento da distribuição de lucros como um indicativo de ser a sociedade empresária ${ }^{13}$ - o fato é que a ausência de um critério adequado para a divisão das espécies societárias em simples e empresária é nitidamente propulsora de insegurança jurídica. A esse respeito, cabe conferir a crítica tecida por Sérgio Campinho (2013, p. 433):

No regime atual, é factível que o Tribunal venha a enquadrar uma sociedade como
empresária, decretando sua falência, com as citadas consequências para seus
integrantes, apesar de eles, em total boa-fé, sem intencionarem travestir qualquer
situação, terem contratado uma sociedade que, nas suas convicções, fosse simples e,
assim, devidamente registrada no Registro Civil de Pessoas Jurídicas. E isso é possível
em face do grau de insegurança jurídica que se tem experimentado com essa bipartição
das sociedades em empresárias e simples.

Além da acurada observação do autor, a dualidade de registros para as sociedades e a vinculação da aquisição da personalidade jurídica à inscrição do contrato no registro próprio agravam o problema. Como destacado ao longo deste, a sociedade formalmente simples e materialmente empresária submete-se à falência como uma sociedade em comum (irregular); seus sócios respondem de modo solidário e ilimitado pelas obrigações sociais; e a falência da pessoa jurídica acarreta, também, a falência de seus sócios.

\footnotetext{
${ }^{13}$ De acordo com o disposto no art. 981 do Código Civil, a partilha dos resultados é inerente a qualquer sociedade, seja simples ou empresária.
} 


\subsection{A sociedade formalmente simples e materialmente empresária e impossibilidade do pedido de recuperação judicial}

A sociedade registrada no Registro Civil das Pessoas Jurídicas que se dedique à exploração de atividade própria de empresário, não poderá requerer recuperação judicial, na medida em que esbarrará no óbice contemplado no caput art. 48 da Lei $\mathrm{n}^{\circ}$. 11.101/2005, que exige o exercício regular (mediante certidão de registro) da empresa por mais de 2 anos ${ }^{14}$.

Justamente por estar impossibilitada de atender ao prefalado requisito formal, a via da recuperação judicial não será aberta à sociedade formalmente simples, mas materialmente empresária, ainda mais se se considerar que se trata de sociedade em comum.

Desse modo, a sociedade com esse perfil se submeterá à falência, tal qual o empresário irregular, nos moldes do já citado art. $1^{\circ}$ da Lei $n^{\circ}$. 11.101/2005, com todos os agravantes declinados ao longo do subitem 5.1, mas não poderá se valer do instituto da recuperação judicial.

\section{A INSOLVÊNCIA DA SOCIEDADE FORMALMENTE EMPRESÁRIA E MATERIALMENTE SIMPLES}

Ao longo dos itens 6.1 e 6.2 infra, será exposto de que modo ou em que medida as sociedades formalmente empresárias (registradas na Junta Comercial), mas materialmente simples por não exercerem atividade própria de empresário sujeito a registro, se submeteriam ou não aos institutos da falência e da recuperação judicial.

\subsection{A sociedade formalmente empresária e materialmente simples e sua sujeição à insolvência civil}

Partindo-se da mesma premissa já declinada segundo a qual não é o registro na Junta Comercial que faz com que uma determinada sociedade seja empresária e, a contrário sensu,

\footnotetext{
${ }^{14}$ Embora não seja o escopo deste trabalho o instituto da recuperação extrajudicial, as conclusões referentes à recuperação judicial são as mesmas para a recuperação extrajudicial, na medida em que esse instituto também se aplica exclusivamente às sociedades empresárias (art. $1^{\circ}$ da Lei $n^{\circ} .11 .101 / 2005$ ) e os requisitos do art. 48 da Lei $\mathrm{n}^{\circ}$. 11.101/2005 também devem ser observados para a homologação do plano de recuperação extrajudicial (art. 161).
}

Rev. de Direitos Fundamentais nas Relações do Trabalho, Sociais e Empresariais | e-ISSN: 2525-9903 | Maranhão | v. 3 | n. 2 | 
não é o registro no Registro Civil das Pessoas Jurídicas que a qualifica como simples e, ainda, à luz do disposto no art. $1^{\mathrm{o}}$ da Lei $\mathrm{n}^{\circ}$. 11.101/2005 tem-se que a sociedade formalmente empresária, mas materialmente simples não se submete ao instituto da falência, mas sim à insolvência civil.

Embora a conclusão acima seja oposta à da sociedade materialmente empresária e formalmente simples, há um detalhe que poderá ter importantes consequências práticas. No caso da sociedade formalmente simples não há registro na Junta Comercial, embora haja exercício de empresa. Assim, é fácil constatar prima facie que se trata de sociedade irregular. Entretanto, para a sociedade formalmente empresária a presunção é favorável à decretação da falência, porque se trata de sociedade regular perante o registro empresarial, com escrituração empresarial, nome empresarial entre outros institutos.

A questão será aplicar a primazia da realidade sobre a forma, isto é, considerar que o modo de exercício da atividade econômica não é empresa pela realidade fática, afastando a presunção de empresarialidade decorrente do registro. Não é fácil, como demonstrado no item 4, pois a concepção de empresa e seus elementos é mais econômica do que jurídica. Prova desta assertiva é que o conceito de empresa decorre de seu perfil subjetivo - o empresário.

Diante da falta de um critério positivado que dê segurança jurídica aos empreendedores e sócios quando desejam constituir uma sociedade, além da repercussão sobre a regulação registral, o ato administrativo regular da Junta Comercial não seria considerado pelo magistrado, que repeliria a presunção decorrente do registro. Só que tal ação estaria fundamentada exclusivamente na doutrina que interpreta como empresa não qualquer atividade econômica, mas apenas aquela com organização de elementos reais e pessoais no estabelecimento para seu exercício profissional.

Afirma-se que o ato registral da Junta Comercial é regular, pois, como visto, não se aplica a teoria da empresa na seara administrativa, limitando-se facultativamente ao requerente a indicar o código de sua(s) atividade(s) segundo a tabela do CNAE, elaborada pelo IBGE. Não obstante, essa regularidade desprezada em juízo, torna a sociedade empresária irregular para fins materiais, por não exercer de fato empresa e ter escolhido o órgão impróprio para seu registro, mas que foi deferido. Nota-se que a imposição da condição de sociedade em comum, 
nesse caso, faz afastar o instituto da falência, ao contrário da hipótese em que a sociedade é formalmente simples, mas materialmente empresária.

Com isso, também se aplica à hipótese em exame o disposto no aludido art. 990 do Código Civil, de modo que todos os seus sócios respondam solidária e ilimitadamente pelas obrigações sociais, tal como ocorre com a sociedade formalmente simples, mas materialmente empresária. Entretanto, ao contrário do que ocorre com as sociedades formalmente simples, mas materialmente empresárias, a declaração de insolvência da sociedade não enseja a insolvência de seus sócios, na medida em que inexiste, na lei processual civil,regras como aquelas constantes dos arts. 81 e 190 da Lei no ${ }^{\circ}$ 11.101/2005.

Desse modo, a declaração de insolvência civil dos sócios de uma sociedade formalmente empresária e materialmente simples dependeria de requerimento próprio e não decorreria naturalmente da declaração de insolvência civil da pessoa jurídica.

\subsection{A sociedade formalmente empresária e materialmente simples e o descabimento do pedido de recuperação judicial}

A sociedade registrada na Junta Comercial que exerça atividade reservada à sociedade simples tampouco poderá valer-se do instituto da recuperação judicial, na medida em que esbarrará no já citado art. $1^{\circ}$ da Lei $n^{\circ}$. 11.101/2005, o qual preservou, no ordenamento jurídico pátrio, o sistema restritivo ${ }^{15}$. Todavia, tais sociedades poderão se valer da chamada concordata civil $^{16}$, estabelecida no art. 783 do Código de Processo Civil de 1973, que depende do consentimento de todos seus credores, mas não da apresentação de um plano de recuperação.

Isso se faz possível porque não há, na lei civil, qualquer preceito que condicione o manejo da concordata civil à regularidade no exercício da atividade ${ }^{17} \mathrm{e}$, como curial em matéria de exegese, "ubi lex voluit dixit, ubi noluit tacuit", ou seja, "quando a lei quis, determinou; sobre o que não quis, guardou silêncio" (MAXIMILIANO, 2007, p. 198).

\footnotetext{
${ }^{15}$ Sobre a preservação do sistema restritivo, confira-se CAMPINHO, 2017, p. 37-38.

${ }^{16}$ Art. 783. O devedor insolvente poderá, depois da aprovação do quadro a que se refere o art. 769, acordar com os seus credores, propondo-lhes a forma de pagamento. Ouvidos os credores, se não houver oposição, o juiz aprovará a proposta por sentença.

${ }^{17}$ Conforme mencionado no item 4.2 acima, o caput do art. 48 da Lei ${ }^{\circ}$. 11.101/2005 condiciona o requerimento da recuperação judicial ao exercício regular da atividade há mais de dois anos.
}

Rev. de Direitos Fundamentais nas Relações do Trabalho, Sociais e Empresariais | e-ISSN: 2525-9903 | Maranhão | v. 3 | n. 2 | 
A despeito das considerações técnicas e dogmáticas acima, é curial sublinhar que também será preciso afastar a presunção de que a requerente é uma sociedade empresária. Se uma sociedade formalmente empresária requer recuperação judicial, ela cumpre prima facie o requisito do art. 48 da Lei $\mathrm{n}^{\circ}$. 11.101/2005, podendo perfeitamente apresentar os documentos exigidos no art. 51, dentre eles a certidão de regularidade no Registro Empresarial. Ademais, a expedição da certidão é ato administrativo regular, com base nas normas técnicas do DREI e no Manual de Atos de Registro (IN DREI n. 38/2017).

Destarte, será preciso que: (i) o juiz não aceite a certidão da Junta Comercial como prova de regularidade, devendo apontar, exclusivamente com base na doutrina e sua interpretação dos arts. 966 e 982 do Código Civil, quais aspectos no modo pelo qual a sociedade exerce a atividade econômica que lhe retiram materialmente a condição de empresária; ou (ii) qualquer credor aponte como objeção à concessão da recuperação a falta do exercício de empresa.

Reconhecida a ilegitimidade ativa da sociedade, o processo deverá ser extinto sem resolução de mérito, eis que não poderá a assembleia de credores aprovar eventual plano de recuperação apresentado.

\section{CONCLUSÃO}

Conforme demonstrado ao longo do item3 deste artigo, a doutrina diverge em relação aos critérios de enquadramento das sociedades como simples e empresárias. E o faz de modo extremo, havendo quem considere que a classificação deva se dar, além da forma, em razão (i) do modo de a sociedade exercer a sua atividade econômica; (ii) do nível de organização; ou (iii) do objeto.

Pode-se afirmar que o atual regime jurídico - e a divergência acima rememorada parece demonstrar isso - padece de segurança jurídica no que tange ao referido enquadramento, sendo certo que, em muitas situações, não é singela a tarefa de classificar uma determinada sociedade como simples ou empresária, mesmo por parte daqueles que estão bem informados e de boa-fé, ou seja, que pretendem implementar a aludida classificação de modo correto, respeitando a legislação vigente, e sem ter qualquer intenção de se mascarar o exercício de atividades próprias de empresário ou próprias de não empresário. A indefinição do quadro das holdings puras e a 
subjetividade que acompanha a expressão "elemento de empresa" contemplada no parágrafo único do art. 966 do Código Civil também se prestam a reforçar essa assertiva.

Atualmente, a classificação das sociedades como simples e empresárias repercute em três esferas: a escrituração, o registro e o regime da insolvência.

Considerando justamente a ausência de critérios claros e objetivos para a realização do enquadramento de sociedades como simples ou empresárias, tem-se que um passo equivocado por ocasião do registro de uma determinada sociedade, ou até a não migração, no momento oportuno, do Registro Civil das Pessoas Jurídicas para a Junta Comercial ou vice-versa, podem trazer consequências nefastas para a sociedade e seus sócios em um cenário de insolvência.

Cumpre enfatizar que, se os critérios de classificação das sociedades fossem bem definidos, aqueles que pretendem explorar uma determinada atividade econômica poderiam mensurar, com segurança, seus riscos. Todavia, no cenário atual, em uma série de situações, à míngua de definições claras, há um campo aberto para consequências indesejadas e extremamente delicadas.

Conforme destacado nos itens 5.1 e 5.2, a sociedade formalmente simples e materialmente empresária se sujeita à falência como uma sociedade empresária irregular, pois a Lei $n^{\circ}$. 11.101/2005 não faz distinção do devedor empresário quanto a inscrição; seus sócios respondem solidária e ilimitadamente pelas obrigações sociais (art. 990 do Código Civil); e a falência da pessoa jurídica acarreta, também, a falência de seus sócios (arts. 81 e 190 da Lei nº. 11.101/2005). Ademais, justamente em função da mencionada irregularidade, não pode a sociedade requerer recuperação judicial (caput do art. 48 da Lei $n^{\circ}$. 11.101/2005).

Por outro lado, como sustentado ao longo dos itens 6.1 e 6.2, preservando-se a coerência do raciocínio estabelecido e tendo em vista a natureza declaratória do registro empresarial, a sociedade formalmente empresária e materialmente simples, por força do disposto no art. $1^{\circ}$ da Lei $\mathrm{n}^{\circ}$. 11.101.2005, não se sujeita à falência, mas sim à insolvência civil. Tal sociedade também se apresenta como uma sociedade irregular, de modo que seus sócios respondem solidária e ilimitadamente pelas obrigações sociais (art. 990 do Código Civil). Todavia, in casu, a sua insolvência não acarreta, de pleno direito, a insolvência de seus sócios. Ademais, também à luz do mencionado art. $1^{\circ}$ da Lei $n^{\circ} 11.101 / 2005$, não poderá se valer da recuperação judicial, mas sim da concordata civil, contemplada no art. 783 do Código de Processo Civil. 


\section{REFERÊNCIAS}

BORBA, José Edwaldo Tavares. Direito societário. 14.ed. São Paulo: Atlas, 2015.

CAMPINHO, Sérgio. Sociedades simples e empresárias: Necessidade de uma revisão de conceitos.In:COELHO, Fábio Ulhoa;LIMA, Thiago Asfor Rocha;NUNES, Marcelo Guedes (Coord.). Reflexões sobre o projeto de Código Comercial. São Paulo: Saraiva, 2013, p. 425436.

Curso de direito comercial: Direito de empresa. 14.ed. São Paulo: Saraiva, 2016.

.Curso de direito comercial: Falência e recuperação de empresa.8.ed. São Paulo: Saraiva, 2017.

COELHO, Fábio Ulhoa. Curso de direito comercial: Direito de empresa.20.ed. São Paulo: Revista dos Tribunais, 2016. v. 2.

LOBO, Jorge Joaquim.Sociedades limitadas. Rio de Janeiro: Forense, 2004. v. I.

MAXIMILIANO, Carlos. Hermenêutica e aplicação do direito. 19.ed. Rio de Janeiro: Forense, 2007.

NEGRÃO, Ricardo. Manual de direito comercial e de empresa. 3.ed. São Paulo: Saraiva, 2003. v. 1.

RIO DE JANEIRO. Tribunal de Justiça. Nona Câmara Cível. Apelação Cível nº $0106837-$ 38.2004.8.19.0001. Rel. Des. Carlos Eduardo Moreira da Silva, julgado em 05.10.2010.

TEPEDINO, Gustavo; BARBOZA, Heloisa Helena; MORAES, Maria Celina Bodin de (Coord.). Código Civil interpretado conforme a Constituição da República. Rio de Janeiro: Renovar, 2011. v. III. 